\title{
Economic Impact on the Re-opened Scalloping Area for Citrus County, Florida-20031
}

Tom Stevens, Charles Adams, Alan Hodges, and David Mulkey²

Bay scallops (Argopecten irradians) are a bivalve shellfish found along the shallow waters of Florida's west coast. They are a popular seafood, and many Florida residents and visitors enjoy harvesting them as a recreational activity. The eye, or adductor muscle, of the scallop is more developed than those in oysters or clams. Scallops can be baked, sautéed, stir-fried, or microwaved, and when cooked properly they remain tender and taste sweet.

Although bay scallops were once common along certain areas of Florida's west coast, their populations began declining after the 1960s. Scallop numbers fell so low in the early 1990s that Florida banned all commercial harvesting after 1994 and restricted recreational harvesting to coastal areas north and west of the Suwannee River between July 1st and September 10th. Between the reduction in harvesting and various restoration programs carried out by the Florida Fish and Wildlife Conservation Commission, the Florida Marine Research Institute, and the University of South Florida, scallop populations increased in some of the closed areas. As a result, in 2002, the coastal area between the Suwannee River and the Weeki Wachee River was reopened for recreational harvesting between July 1 st and September 10th.
The entire coast of Citrus County lies along this newly reopened scalloping area, and the additional economic activity brought back by recreational scallopers has been welcomed by many local businesses. To help quantify the economic significance of the restored scalloping season for Citrus County, a survey of related businesses on the west side of US Highway 19/98 in the coastal areas of the county was conducted during the summer of 2003. Businesses located on the east side of this section of the highway were deemed unlikely to have experienced any revenue changes due to the renewed scalloping season. General merchandise retailers and owners or managers of recreational guide services, dive shops, restaurants, motels, convenience stores, and gas stations were interviewed about changes in business revenues experienced during the most recent scalloping season in relation to the comparable period prior to the reopening. Ninety-nine usable interviews were completed from a population of 608 related businesses in the area (Citrus County, Florida, Tourism Development Office).

To estimate the increased revenues due to the renewed recreational scalloping in Citrus County, the revenue increases reported in the survey were extrapolated in proportion to the percentage of types

1. This is EDIS document FE493, a publication of the Department of Food and Resource Economics, Florida Cooperative Extension Service, UF/IFAS, University of Florida, Gainesville, FL. Published August 2004. Please visit the EDIS website at http://edis.ifas.ufl.edu.

2. Tom Stevens, Post-Doctoral Associate; Charles Adams, Professor; Alan Hodges, Associate-In; and David Mulkey, Professor and Associate Chair, Department of Food and Resource Economics, Florida Cooperative Extension Service, UF/IFAS, University of Florida, Gainesville, FL. 
of businesses interviewed (interviewed businesses were representative of all businesses on the west side of Citrus County). For example, 42 out of 75 (56\%) of the dive shops and nature guides listed in Citrus County's occupational license rolls and located west of Highway 19/98 were interviewed for the survey. These businesses reported a combined increase in revenues of $\$ 59,300$, or $\$ 1,411.90$ each (Table 1 ). Assuming this average is representative for all dive shops and nature guides, the total increase in revenues for these types of businesses as a result of the renewed scalloping season can be estimated by multiplying it by the total number of those businesses in the area (i.e., $\$ 1,411.90 \times 75=\$ 105,893$ ).

When evaluating the impact of new business to a local economy, it is important to distinguish between local and non-local or outside revenues. Local revenue (spending by local residents at local businesses) represents simple transfers within that economy and do not create any economic spin-offs. New or outside revenue from spending by non-local residents generates additional economic activity through indirect and induced impacts. Indirect impacts occur as local businesses purchase the necessary goods and services to meet the additional demands of visiting scallopers. Induced impacts occur as households of employees, managers, and business owners spend their additional income at other businesses in the area for the everyday necessities of life.

Based on additional data collected in the survey, the proportion of revenues originating from outside the county was estimated for each type of business (Table 1). These proportions ranged from $73 \%$ for lodging to $46 \%$ for convenience stores and gas stations. In Table 1, estimates of revenue coming from outside the county are referred to as "non-local" revenues. It was estimated that $\$ 867,196$ of the total $\$ 1,444,339$ in additional revenues from scallopers originated from outside the county, with the remaining $\$ 577,142$ coming from local residents (Table 1).

These revenue estimates were entered into a regional economic modeling software package, IMPLAN Pro (Minnesota IMPLAN Group, 2002). IMPLAN includes a detailed county-level database of the U.S. economy, which makes it possible to quickly construct detailed input-output models for regional economies. Such models mathematically describe and quantify the economic relationships and interactions within a defined economic region. Once constructed, they can be used to estimate how new revenue for particular businesses or events impacts all types of businesses and institutions in a local or regional economy.

A summary of the estimated annual economic impacts from renewed scallop fishing revenues in Citrus County, Florida is shown in Table 2. Output, value added, labor income, indirect business taxes, and employment impacts are shown in individual rows, while local and non-local direct, indirect, induced, and total economic impacts are arranged in table columns. Output impacts (shown in top row of Table 2) are a gross measure of economic activity flowing from revenues generated by the renewed scallop fishing activity. The total output impacts on the county's economy are estimated to be $\$ 1.64$ million for 2003. Value-added impacts (labor and management income), returns to ownership, and indirect business taxes generated by an economic activity were estimated to be $\$ 982,253$ in 2003 . The labor income component of the value-added impact was estimated to equal nearly $\$ 636,300$ for Citrus County. Indirect business taxes resulting from the new fishing activity include excise, property, and sales taxes, as well as licensees and fees paid by businesses, but do not include taxes on profit or income. These tax impacts were estimated at approximately $\$ 110,000$. Employment impacts approximate the number of full-time and part-time jobs created by an economic activity and are based on industry-average output per worker statistics. A total of 35 jobs were estimated to have been created by the additional revenues from scallopers visiting Citrus County.

Direct impacts (shown in Table 2) represent the additional revenues and jobs generated by Citrus County's businesses that directly interacted with local and visiting scallopers. (Assuming local residents would spend this money within the county regardless of the reopening of the scalloping season, there would not be any net economic impact from the local revenue shown in Table 2). Indirect impacts from 
non-local revenue estimate the additional economic activity generated when these businesses purchase inputs (e.g., supplies, fuel, and utilities) from other local businesses. Further indirect impacts occur when these input supply businesses purchase their own inputs. The total indirect-output impact due to non-local scallop fishing revenues in Citrus County is estimated to be $\$ 165,343$ for 2003 . When business employees, managers, and owners spend their earnings from non-local revenues to purchase goods and services from other businesses within the county, they generate "induced" impacts for that economy. The induced-output impacts from scalloping were estimated to be nearly $\$ 349,000$ for Citrus County.

Economic impact analysis permits decision makers to look beyond the direct revenues and jobs generated by an industry or event when considering its importance in a regional economy. Indirect economic impacts indicate how important the renewed scalloping season is to area businesses that serve other businesses. Direct and induced impacts point to how significant the scalloping activity is for area businesses that serve scallopers and consumers in general. Output, value added, income, and jobs are basic units for measuring economic activity, and permit one to compare the impact of a particular industry or event to that of the overall economy or to other industries or sectors in the region. Altogether, these estimated direct, indirect, and induced impacts give a more complete picture of how the additional revenues from recreational scalloping are impacting Citrus County's economy. 
Table 1. Additional revenues for new scalloping area off Citrus County, 2003.

\begin{tabular}{|lcccccc|}
\hline \hline \multicolumn{1}{|c}{ Business Type } & $\begin{array}{c}\text { Sampled } \\
\text { Revenue } \\
\text { Increase }\end{array}$ & $\begin{array}{c}\text { Firms } \\
\text { Interviewed }\end{array}$ & $\begin{array}{c}\text { Extrapolated } \\
\text { Revenue } \\
\text { Increase }\end{array}$ & $\begin{array}{c}\text { Non-local } \\
\text { Revenues }\end{array}$ & $\begin{array}{c}\text { Extrapolated Revenue } \\
\text { Increase }\end{array}$ \\
\hline Guides/Dive Shops & $\$ 59,300$ & $56.0 \%$ & $\$ 105,893$ & $70.0 \%$ & $\$ 74,125$ & $\$ 31,768$ \\
Restaurants & $\$ 25,000$ & $6.2 \%$ & $\$ 401,409$ & $50.0 \%$ & $\$ 200,704$ & $\$ 200,704$ \\
Lodging & $\$ 260,204$ & $54.5 \%$ & $\$ 477,041$ & $73.0 \%$ & $\$ 348,240$ & $\$ 128,801$ \\
$\begin{array}{l}\text { Convenience Stores/ } \\
\text { Gas Stations }\end{array}$ & $\$ 16,000$ & $30.0 \%$ & $\$ 53,387$ & $46.0 \%$ & $\$ 24,558$ & $\$ 28,829$ \\
Retailers & $\$ 122,750$ & $30.2 \%$ & $\$ 406,609$ & $54.0 \%$ & $\$ 219,569$ & $\$ 187,040$ \\
Total & $\$ 483,254$ & $\$ 1,44,339$ & $60.0 \%$ & $\$ 867,196$ & $\$ 577,142$ \\
\hline Source: Citrus County, Florida, Tourism Development Office. & & & & & \\
\hline \hline
\end{tabular}

Table 2. Economic impacts of the new scalloping area, Citrus County, Florida, 2003. *

\begin{tabular}{|c|c|c|c|c|c|}
\hline \multirow[t]{2}{*}{ Impact Type/Level } & \multirow{2}{*}{$\frac{\text { Local }}{\text { Direct }}$} & \multicolumn{3}{|c|}{ Non-local } & \multirow[t]{2}{*}{ Total } \\
\hline & & Direct & Indirect & Induced & \\
\hline Output (\$) & $\$ 427,013$ & $\$ 698,278$ & $\$ 165,343$ & $\$ 348,752$ & $\$ 1,639,386$ \\
\hline Value Added (\$) & $\$ 248,228$ & $\$ 409,293$ & $\$ 102,541$ & $\$ 222,191$ & $\$ 982,253$ \\
\hline Labor Income (\$) & $\$ 165,135$ & $\$ 269,059$ & $\$ 63,306$ & $\$ 138,800$ & $\$ 636,300$ \\
\hline Indirect Business Taxes (\$) & $\$ 32,875$ & $\$ 51,172$ & $\$ 7,361$ & $\$ 18,620$ & $\$ 110,028$ \\
\hline Employment (Jobs) & 11 & 17 & 2 & 5 & 35 \\
\hline \multicolumn{6}{|c|}{$\begin{array}{l}\text { * Total impacts equal the sum of direct, indirect, and induced impacts. Output, value added, labor income, indirect taxes, } \\
\text { and employment represent different measures of economic activity and cannot be added together. }\end{array}$} \\
\hline
\end{tabular}

